\title{
ANALISA TERHADAP PUTUSAN MAHKAMAH KONTITUSI NOMOR 46/PUU-VIII/2010 MENGENAI STATUS ANAK*
}

\author{
DARDA PASMATUTI \\ Sekolah Tinggi Ilmu Hukum Putri Maharaja Payakumbuh \\ Koto Kociak, Kecamatan Guguak, Kabupaten 50 Kota \\ e-mail: darda.pasmatuti16@gmail.com
}

\begin{abstract}
Marriage is a sacred part of life, because it must pay attention to norms and rules of life in society. But in reality, not everyone is so principled, with a variety of justifiable reasons that are reasonable and acceptable to society, marriage is often not appreciated for its sanctity. Marriage is a medium that will unite two people in a household. Marriage is the only unifying rite of two persons officially recognized in both state law and religious law. Problem under study is to analyze the decision of Constitutional Court Number 46/PUU-VIII/2010 regarding the status of children, in this case the research method used is descriptive research that emphasizes the data in the form of narrative and argumentation of words and not on data in the form of numbers, numbers. Using the normative juridical approach of trying to learn every legal material that is related to the subject of the study and then comparing with the rules of legislation, theories and opinions of experts on the issues discussed. Test material submitted from Hj. Aisha Mochtar to the Constitutional Court regarding the provisions of Article 2 and Article 43 paragraph (1) of Law no. 1 of 1974 concerning Marriage of Article 28 B Paragraph (1) and (2) of the 1945 Constitution relating to the Rights of the Child and Article $28 D$ of the 1945 Constitution relating to the right of everyone to the recognition, guarantee, protection and certainty of equitable law and equal treatment in before the law. Article 2 of Law no. 1 Year 1974, related to legitimated marriage is marriage recorded at the institution of marriage. Meanwhile, Article 43 of Law no. 1 Year 1974, related to the status of children outside marriage. The test of the material is granted in decision No. 46/PUU-VIII/2010. Which will be discussed is the Decision Analysis of the Constitutional Court. Decision 46/PUU-VIII/2010 child status.
\end{abstract}

Keywords: Verdict, Child Status

\section{Abstrak}

Perkawinan merupakan bagian hidup yang sakral, karena harus memperhatikan norma dan kaidah hidup dalam masyarakat. Namun kenyataannya, tidak semua orang berprinsip demikian, dengan berbagai alasan pembenar yang cukup masuk akal dan bisa diterima masyarakat, perkawinan sering kali tidak dihargai kesakralannya. Pernikahan merupakan sebuah media yang akan mempersatukan dua insan dalam sebuah rumah tangga. Pernikahan adalah satu-satunya ritual pemersatu dua insan yang diakui secara resmi dalam hukum kenegaraan maupun hukum agama. Masalah yang diteliti adalah menganalisa terhadap putusan Mahkamah Konstitusi Nomor 46/PUU-VIII/2010 mengenai status anak, dalam hal ini metode penelitian yang dipakai adalah penelitian deskriptif yang lebih menekankan pada data berupa narasi dan argumentasi kata-kata dan bukan pada data berupa angka-angka. Menggunakan pendekatan yuridis normatif yaitu berusaha mempelajari setiap bahan hukum yang terkait dengan bahasan penelitian kemudian membandingkan dengan peraturan perundanga-undangan, teori serta pendapat para ahli mengenai persoalan yang dibahas. Uji materi yang diajukan Hj. Aisyah Mochtar kepada MK mengenai ketentuan Pasal 2 dan Pasal 43 ayat (1) UU No. 1 Tahun 1974 tentang Perkawinan terhadap pasal 28 B ayat (1) dan (2) UUD 1945 terkait dengan hak asasi anak dan pasal 28 D UUD 1945 terkait hak setiap orang atas pengakuan, jaminan, perlindungan dan kepastian hukum yang adil dan perlakuan yang sama di depan hukum. Pasal 2 UU No. 1 Tahun 1974, terkait dengan perkawinan yang sah adalah perkawinaan yang tercatat pada lembaga perkawinan. Sedangkan pasal $43 U U$

* Naskah diterima: 31 Agustus 2017, direvisi: 07 Sebtember 2017, disetujui untuk terbit: 10 Sebtember 2017 
Darda Pasmatuti: Analisa Terhadap Putusan Mahkamah Kontitusi No.46/PUU-VII/2010...

No. 1 Tahun 1974, terkait dengan status anak luar nikah. Uji materi tersebut dikabulkan dalam putusan No. 46/PUU-VIII/2010. Yang akan dibahas adalah Analisa Putusan MK No. Putusan 46/PUU-VIII/2010 status anak.

Kata kunci: Putusan, Status Anak

\section{PENDAHULUAN}

Hukum adalah aturan normatif yang mengatur perilaku manusia. Itu tidak tumbuh dalam ruang hampa, melainkan dibangun di atas masyarakat kesadaran peraturan kolektif. Hukum harus maju untuk bersaing dengan nilai-nilai tumbuh dalam masyarakat, termasuk adat, tradisi, dan agama. Teori hukum Islam menyebut mereka al-adat muhkamat, yang berarti bahwa tradisi atau kebiasaan di masyarakat bisa menjadi Undangundang. ${ }^{1}$

Salah satu hal yang diatur melalui hukum itu sendiri adalah masalah perkawinan. Berlakunya Undang-undang Nomor 1 Tahun 1974 tentang Perkawinan menjadikan peraturan tersebut sebagai hukum pertama di Indonesia yang mengatur pernikahan dalam skala nasional. Sebelum itu, pernikahan telah diatur melalui beberapa hukum seperti hukum bagi warga umum, hukum Islam untuk warga Muslim dan Kristen Indonesia, peraturan pernikahan untuk warga Kristen di Jawa, Minahasa dan Ambon, Kode Hukum Sipil untuk warga keturunan Eropa dan Cina, peraturan pernikahan untuk pernikahan antar agama. $^{2}$

1 Jalaludin Al-Sayuthi, Al-Asybah wa AlNazhair, (Translet by google), Hlm.63 di akses pada tanggal 19 Februari 2012, pukul 19.00 WIB.

${ }^{2}$ Wirjono Prodjodikoro, Hukum Perkawinan di Indonesia, Vorkink van Hoeve, Bandung, Hlm. 77
Pelaksanaan perkawinan di Indonesia selalu bervariasi bentuknya. Mulai dari perkawinan lewat Kantor Urusan Agama (KUA), perkawinan bawa lari, sampai perkawinan yang populer di kalangan masyarakat dengan sebutan kawin siri. Perkawinan yang tidak dicatatkan atau yang dikenal dengan berbagai istilah lain seperti 'kawin bawah tangan', 'kawin siri' atau 'nikah sirri', adalah perkawinan yang dilakukan berdasarkan aturan agama atau adat istiadat dan tidak dicatatkan di kantor pegawai pencatat nikah (KUA bagi yang beragama Islam, Kantor Catatan Sipil bagi non-Islam). Istilah sirri berasal dari bahasa arab sirra, israr yang berarti rahasia. Kawin siri, menurut arti katanya, perkawinan yang dilakukan dengan sembunyi-sembunyi atau rahasia. ${ }^{3}$ Selain nikah siri adapula perkawinan secara biologis atau disebut zina. Zina juga mengakibatkan akibat hukum yaitu munculnya anak luar kawin.

Disebutkan dalam pasal 2 ayat (1) Undang Undang Nomor 1 tahun 1974 Tentang Perkawinan disebutkan "Tiaptiap perkawinan dicatat menurut peraturan perundang-undangan yang berlaku“.Pasal 43 ayat (2) Undang Undang Nomor 1 tahun 1974 Tentang Perkawinan disebutkan "Anak yang dilahirkan di luar perkawinan hanya

\footnotetext{
${ }^{3}$ Mahmud Yunus, 1979, Hukum Perkawinan Dalam Islam, Hidakarya Agung, Jakarta, Hlm. 176
} 
mempunyai hubungan perdata dengan ibunya dan keluarga ibunya”.

Sebelum adanya putusan Mahkamah Konstitusi No. 46/PUU-VIII/2010, jika ditinjau dari pengaturan yang terdapat dalam Undang Undang Nomor 1 Tahun 1974 Tentang Perkawinan, anak-anak yang dilahirkan dari hasil nikah siri status hukumnya sama dengan anak luar kawin hasil zina yakni hanya punya hubungan hukum dengan ibunya. Hal ini membawa konsekuensi, anak yang lahir dari kawin siri dan juga zina, secara hukum negara tidak mempunyai hubungan hukum dengan ayahnya. Hal tersebut antara lain akan terlihat dari akta kelahiran si anak. Dalam akta kelahiran anak yang lahir dari perkawinan siri tercantum bahwa telah dilahirkan seorang anak bernama siapa, hari dan tanggal kelahiran, urutan kelahiran, nama ibu dan tanggal kelahiran ibu atau menyebut nama ibu saja, tidak menyebut nama ayah si anak.

Selain itu, konsekuensi dari tidak adanya hubungan antara ayah dan anak secara hukum juga berakibat anak luar kawin tidak mendapat warisan dari ayah biologisnya. Anak yang lahir di luar perkawinan atau sebagai akibat hubungan suami isteri yang tidak sah menurut hukum, hanya mempunyai hubungan nasab, hak dan kewajiban nafkah serta hak dan hubungan kewarisan dengan ibunya serta keluarga ibunya saja, tidak dengan ayah/bapak alami (genetiknya), kecuali ayahnya tetap mau bertanggung jawab dan tetap mendasarkan hak dan kewajibannya menurut hukum Islam. Perkawinan siri tidak dapat mengingkari adanya hubungan darah dan keturunan antara ayah biologis dan si anak itu sendiri. Begitu juga ayah/bapak alami (genetik) tidak sah menjadi wali untuk menikahkan anak alami (genetiknya), jika anak tersebut kebetulan anak perempuan. Jika anak yang lahir di luar pernikahan tersebut berjenis kelamin perempuan dan hendak melangsungkan pernikahan maka wali nikah yang bersangkutan adalah wali Hakim, karena termasuk kelompok yang tidak mempunyai wali.

Kasus melibatkan Machica Moerdiono. Mahkamah Konstitusi dalam Keputusan Mahkamah Konstitusi Nomor Putusan 46/PUU-VIII/2010 memberikan putusan mengabulkan sebagian permohonan para pemohon. Bahwa seorang anak yang lahir diluar nikah, berhak untuk mempunyai hubungan perdata ataupun hak mewarisi dari ayah biologisnya.

Uji Materi terhadap Pasal 2 Ayat (2) Pasal 43 ayat (1) Undang-Undang Nomor 1 Tahun 1974 tentang Perkawinan dengan pasal 28 B ayat (1) dan (2) dan pasal $28 \mathrm{D}$ UUD 1945. Menurut pasal 43 ayat (1) Undang Undnag Perkawinan disebutkan bahwa anak yang lahir di luar perkawinan hanya mempunyai hubungan perdata dengan ibunya dan keluarga ibunya. Kedudukan anak diluar kawin ini akan diatur dalam Peraturan Pemerintah.

Undang Undang Nomor 1 tahun 1974 pasal 2 ayat 2 menyebutkan "Tiap-tiap perkawinan dicatat menurut peraturan perundang-undangan yang berlaku". Sedangkan Pasal 43 ayat (1) UndangUndang Nomor 1 Tahun 1974 tentang 
Darda Pasmatuti: Analisa Terhadap Putusan Mahkamah Kontitusi No.46/PUU-VII/2010...

Perkawinan disebutkan bahwa "Anak yang lahir di luar perkawinan hanya mempunyai hubungan perdata dengan ibunya dan keluarga ibunya".

Pasal 28 B ayat (1) Undang Undang Dasar Tahun 1945 disebutkan "Setiap orang berhak membentuk keluarga dan melanjutkan keturunan melalui perkawinan yang sah”. Sedangkan dalam Pasal 28 B ayat (2) Undang Undang Dasar Tahun 1945 disebutkan sebagai berikut "Setiap anak berhak atas kelangsungan hidup, tumbuh, dan berkembang serta berhak atas perlindungan dari kekerasan dan diskriminasi". Pasal 28 D ayat (1) Undang Undang Dasar Tahun 1945 disebutkan sebagai berikut "Setiap orang berhak atas pengakuan, jaminan, perlindungan, dan kepastian hukum yang adil serta perlakuan yang sama di hadapan hukum”.

Uji materi yang diajukan $\mathrm{Hj}$. Aisyah Mochtar akhirnya dikabulkan, akibatnya aturan yang terkandung dalam pasal 43 ayat (1) Undang Undang Nomor 1 Tahun 1974 tentang Perkawinan yang menyebutkan bahwa Anak yang dilahirkan di luar perkawinan hanya mempunyai hubungan perdata dengan ibunya dan keluarga ibunya dibatalkan oleh MK melalui putusan: 46/PUUVIII/2010.

Pasal 43 ayat 1 Undang Undang Perkawinan dibatalkan oleh putusan MK Nomor 46/PUU-VIII/2010 dengan alasan hukum bahwa hubungan anak dengan seorang laki-laki sebagai bapak tidak semata-mata karena adanya ikatan perkawinan, akan tetapi dapat juga didasarkan pada pembuktian adanya hubungan darah antara anak dengan lakilaki tersebut sebagai bapak. Dengan demikian, terlepas dari soal prosedur/administrasi perkawinannya, anak yang dilahirkan harus mendapat perlindungan hukum. Jika tidak demikian, maka yang dirugikan adalah anak yang dilahirkan di luar perkawinan, padahal anak tersebut tidak berdosa karena kelahirannya di luar kehendaknya.

Maka penulis ingin melihat lebih mendalam mengenai anaisa putusan Mahkamah Konstitusi Nomor Putusan 46/PUU-VIII/2010. Dengan harapan akan memperjelas kedudukan anak secara normatif. Maka penelitian ini ditujukan untuk mengetahui dan memahami analisa Putusan Mahkamah Konstitusi Nomor Putusan 46/PUU-VIII/2010 tentang status anak.

\section{METODE PENELITIAN}

Jenis penelitian deskriptif yang lebih menekankan pada data berupa narasi dan argumentasi kata-kata dan bukan pada data berupa angka-angka. Menggunakan pendekatan yuridis normatif yaitu berusaha mempelajari setiap bahan hukum yang terkait dengan bahasan penelitian kemudian membandingkan dengan peraturan perundanga-undangan, teori serta pendapat para ahli mengenai persoalan yang dibahas.

Pembahasan penelitian ini menggunakan metode pengkajian kepustakaan atau Library research. Library Research, yaitu studi yang 
menekankan pengambilan data berdasarkan karya ilmiah yang diperoleh pada studi literatur atau pustaka. Oleh sebab itu, penulisa karya ilmiah ini akan dilakukan berdasarkan atas hasil studi terhadap beberapa bahan pustaka berupa peraturan perundang-undangan dan berbagai literatur, dokumen, makalah, skripsi, tesis dan karya ilmiah lainnya yang berkaitan dengan status anak luar nikah.

Penelitian ini menggunakan dua bentuk jenis data penelitian yaitu:

a. Sumber Primer adalah referensi- referensi yang berkaitan dengan hukum positif yaitu Putusan Mahkamah Konstitusi Nomor 46/PUU-VIII/2010 mengenai Status Anak.

b. Sumber Sekunder adalah karya-karya para pakar hukum dan referensi-referensi lain yang memiliki keterkaitan dengan status anak terkait dengan keluarnya Putusan Mahkamah Konstitusi Nomor 46/PUU-VIII/2010.

Urgensi sumber sekunder tentunya dimaksudkan sebagai bahan pertimbangan dalam rangka kepentingan analisis.

Guna kepentingan pengolahan data, maka langkah yang penulis lakukan adalah sebagai berikut:

a. Mengidentifikasi, yaitu penulis berusaha mengenali objek permasalahan penelitian dengan mengetahui pengertian (epistimology), sejarah (history) berlakunya hukum (KHI dan UU No. 1 Tahun 1974), pendapat para ahli (doktrin) dan Putusan Mahkamah Konstitusi Nomor 46/PUU-VIII/2010 mengenai Status Anak.

b. Klasifikasi, yaitu penulis akan berusaha mengelompokkan hasil identifikasi diatas pada kelompok yang sejalan dan dapat digolongan sama.

c. Analisa Data, yaitu data yang telah di identifikasi dan di klasifikasikan seperti langkah sebelumnya akan penulis analisa.

d. Penarikan kesimpulan, setelah melakukan identifikasi, klasifikasi dan analisa, maka penulis akan berusaha menarik kesimpulan.

Sedangkan dalam menganalisa data, maka penulis menggunakan analisis konteks, jadi hanya terfokus pada konteks permasalahan yaitu status anak menurut putusan Mahkamah Konstitusi Nomor: 46/PUU-VIII/2010. Cara ini dimaksudkan untuk menganalisis makna sesungguhnya yang terkandung dalam keseluruhan Putusan Mahkamah Konstitusi tersebut. Kemudian dibandingkan dengan teori atau pendapat para ahli dan logika penulis.

\section{HASIL DAN PEMBAHASAN}

Perkawinan merupakan bagian hidup yang sakral, karena harus memperhatikan norma dan kaidah hidup dalam masyarakat. Namun kenyataannya, tidak semua orang berprinsip demikian, dengan berbagai alasan pembenar yang cukup 
Darda Pasmatuti: Analisa Terhadap Putusan Mahkamah Kontitusi No.46/PUU-VII/2010...

masuk akal dan bisa diterima masyarakat, perkawinan sering kali tidak dihargai kesakralannya. Pernikahan merupakan sebuah media yang akan mempersatukan dua insan dalam sebuah rumah tangga. Pernikahan adalah satu-satunya ritual pemersatu dua insan yang diakui secara resmi dalam hukum kenegaraan maupun hukum agama.

Pelaksanaan perkawinan di Indonesia selalu bervariasi bentuknya. Mulai dari perkawinan lewat Kantor Urusan Agama (KUA), perkawinan bawa lari, sampai perkawinan yang populer dikalangan masyarakat, yaitu kawin siri. Perkawinan yang tidak dicatatkan atau yang dikenal dengan berbagai istilah lain seperti "kawin bawah tangan", adalah perkawinan yang dilakukan berdasarkan aturan agama atau adat istiadat dan dicatatkan dikantor pegawai pencatat nikah (KUA bagi yang beragama Islam, Kantor Catatan Sipil bagi non-muslim). Istilah sirri berasal dari bahsa arab sirra, israr yang berarti rahasia. Kawin siri, menurut arti katanya, perkawinan yang dilakukan dengan sembunyi-sembunyi atau rahasia. ${ }^{4}$ Kawin siri tidak disaksikan orang banyak dan tidak dilakukan di hadapan pegawai pencatat nikah. Kawin itu dianggap sah menurut agama tetapi melanggar ketentuan pemerintah. ${ }^{5}$ Akibat lebih jauh dari perkawinan yang tidak tercatat adalah, anak-anak yang dilahirkan dari perkawinan tersebut tidak berhak

\footnotetext{
${ }^{4}$ Mahmud Yunus, 1979, Hukum Perkawinan Dalam Islam, Hidakarya Agung, Jakarta, Hlm. 56

5 Saidus Syahar, 1981, Undang-undang Perkawinan dan Masalah Pelaksanaannya Ditinjau dari Segi Hukum Islam, Alumni, Bandung, Hlm. 22
}

menuntut nafkah, biaya pendidikan ataupun warisan dari ayahnya. ${ }^{6}$

Kedudukan anak diatur di dalam Undang-undang Nomor 1 Tahun 1974 tentang Perkawinan dalam Bab IX Pasal 42 sampai Pasal 43. Masalah kedudukan anak ini, terutama adalah dalam hubungannya dengan pihak bapaknya, sedangkan terhadap pihak ibunya secara umum dapat dikatakan tidak terlalu susah untuk mengetahui siapa ibu dari anak yang dilahirkan tersebut. Untuk mengetahui siapa ayah dari seorang anak, masih dapat menimbulkan kesulitan. Bagi seseorang, anak dianggap selalu mempunyai hubungan hukum dengan ibunya. Dengan pihak bapak, anak tidaklah demikian. Anak tidak mempunyai hubungan hukum dengan pihak ayah yang telah membenihkannya. ${ }^{7}$

Menurut Kitab Undang-undang Hukum Perdata, dengan perkawinan suami isteri memperoleh keturunan. Yang dimaksudkan dengan "keturunan" disini adalah hubungan darah antara bapak, ibu dan anak-anaknya. Jadi antara bapak dan ibu serta anak ada hubungan biologis. Anak-anak yang dilahirkan dari hubungan biologis ini dan ditumbuhkan sepanjang perkawinan adalah anak-anak sah (wettige of echte kinderen). ${ }^{8}$ Sedangkan anak-anak lainnya, yakni anak yang mempunyai ibu

6 Http://www.lbh-apik.or.id, diakses pada hari minggu tanggal 28 Maret 2012, pada pukul 19.00 WIB

7 Wahono Darmabrata dan Surini Ahlan Sjarif, 2004, Hukum Perkawinan dan Keluarga di Indonesia, Fakultas Hukum Universitas Indonesia, Jakarta, Hlm. 131

8 Martiman Prodjohamijojo, 2007, Hukum Perkawinan Indonesia, Cet.II, Indonesia Legal Center Publishing, Jakarta, HIm. 53. 
dan bapak yang tidak terikat dengan perkawinan, dinamakan anak tidak sah, atau anak di luar nikah juga sering disebut anak-anak alami atau onwetting onechte of natuurlijke kinderen. Jadi terhadap anak yang lahir di luar nikah terdapat hubungan biologis hanya dengan ibunya tetapi tidak ada hubungan biologis dengan ayahnya. $^{9}$

$\begin{array}{llr}\begin{array}{c}\text { Berdasarkan } \\ \text { Undang-Undang }\end{array} \text { Hukum } & \text { Kitab } \\ \text { Perdata } \\ \text { pengertian anak luar kawin dibagi } \\ \text { menjadi dua yaitu dalam arti luar dan } \\ \text { dalam arti sempit. Anak luar kawin dalam } \\ \text { arti luas meliputi anak zina, anak }\end{array}$
sumbang dan anak luar kawin lainnya. Sedangkan anak luar kawin dalam arti sempit, artinya tidak termasuk anak zina dan anak sumbang, anak luar kawin dalam arti sempit ini yang dapat diakui. Sedangkan dalam islam anak luar kawin disebut sebagai anak zina.

Anak zina adalah anak yang lahir dari suatu hubungan kelamin antara laki-laki dengan perempuan yang tidak terikat dalam nikah yang sah meskipun ia lahir dalam suatu perkawinan yang sah dengan laki-laki yang melakukan zina atau lakilaki lain.meskipun anak zina itu mempunyai status hukum yang sama dengan anak li'an yaitu sama-sama tidak sah, namun perbedaan antara keduanya adalah bahwa anak zina telah jelas statusnya dari awal, seperti lahir dari perempuan yang tidak bersuami sedangkan anak li'an lahir dari perempuan yang bersuami, namun tidak diakui anak tersebut oleh suaminya. Anak

\footnotetext{
${ }^{9}$ Ibid, Hlm. 54
}

zina itu tidak mempunyai hubungan nasab dengan laki-laki yang menyebabkan ia lahir. $^{10}$

Kalau dilihat di dalam lingkungan Hukum Adat, Hukum Islam, maupun di dalam Kitab Undang-Undang Hukum Perdata (BW), anak-anak dari si peninggal warisan merupakan golongan yang terpenting dan yang utama. Dr Wirjono dalam bukunya Hukum Waris di Indonesia, antara lain menyebutkan bahwa oleh karena mereka (anak-anak) pada hakikatnya merupakan satu-satunya golongan ahli waris, artinya sanak keluarga tidak menjadi ahli waris apabila si peninggal warisan meninggalkan anakanak. $^{11}$ Pengaturan mengenai Hukum Waris di Indonesia masih beraneka ragam karena adanya sifat pluralistik dengan berlakunya tiga sistem hukum kewarisan, yaitu Hukum Waris Adat, Hukum Waris Islam, dan Hukum Waris Kitab UndangUndang Hukum Perdata. Dikarenakan bahwa sesungguhnya dalam kehidupan masyarakat di dunia ini memiliki kondisi kekeluargaan yang berbeda-beda, dari inilah keadaan warisan dari masyarakat itu tergantung dari masyarakat tertentu yang ada kaitannya dengan kondisi kekeluargaan serta membawa dampak pada kekayaan dalam masyarakat tersebut. $^{12}$

${ }^{10}$ Amir Syarifudin, 2005, Hukum Kewarisan Islam, Cet. II, Prenada Media, Jakarta, Hlm. 148.

11 Soedharyo Soimin, 2004, Hukum Orang dan Keluarga, Cet. II, Sinar Grafika, Jakarta, Hlm. 31 .

12 Oemarsalim, 2006, Dasar-dasar Hukum Waris di Indonesia, Cet. IV, Sinar Grafika, Jakarta, Hlm. 5. 
Mengenai masalah kewarisan bagi anak luar kawin, hukum di Indonesia memberikan solusi agar anak luar kawin dapat memperoleh bagian warisan dari ayahnya, yaitu dengan cara diakuinya anak tersebut oleh ayahnya. Namun pengakuan anak luar kawin ini hanya diperuntukan bagi golongan keturunan Tionghoa yang diatur dalam Kitab Undang-Undang Hukum Perdata. Dalam Kitab Undang-Undang Hukum Perdata hak waris anak luar kawin yang diakui diatur dalam Pasal 862-866 dan Pasal 867 ayat (1). Ahli waris anak di luar kawin timbul jika pewaris mengakui dengan sah anak luar kawin tersebut. Syarat agar anak luar kawin dapat mewaris ialah bahwa anak tersebut harus diakui dengan sah oleh orang tua yang membenihkannya. Kitab Undang-Undang Hukum Perdata dianut prinsip bahwa, hanya mereka yang mempunyai hubungan hukum dengan pewaris yang berhak mewaris. Hubungan hukum antara anak luar kawin dengan ayah ibunya, timbul sesudah ada pengakuan dari ayah ibunya tersebut. Hubungan hukum tersebut bersifat terbatas, dalam arti hubungan hukum itu hanya ada antara anak luar kawin yang diakui dengan ayah ibu yang mengakuinya saja. ${ }^{13}$

Bagian seorang anak yang lahir di luar perkawinan, tetapi diakui (erkend natuurlijk), itu tergantung dari berapa adanya anggota keluarga yang sah. Jika ada ahli waris dari golongan pertama maka bagian anak yang lahir di luar

${ }^{13}$ Surini Ahlan Sjarif dan Nurul Elmiyah, 2006, Hukum Kewarisan Perdata Barat, Cet. II, Kencana Media Group, Jakarta, Hlm. 87. perkawinan tersebut sepertiga dari bagian yang akan diperolehnya seandainya ia dilahirkan dari perkawinan yang sah. Dan jikalau ia bersama-sama mewaris dengan anggota-anggota keluarga dari golongan kedua, bagiannya menjadi separoh dari bagian yang akan diperolehnya seandainya ia dilahirkan dari perkawinan yang sah. Pembangian warisan, harus dilakukan sedemikian rupa, sehingga anak yang lahir di luar perkawinan itu, harus dihitung dan dikeluarkan lebih dahulu barulah sisanya dibagi antara ahli waris yang lainnya, seolah-olah sisa warisan itu utuh.

Mengenai anak-anak yang lahir di luar kawin dan tidak diakui terdapat 2 golongan: ${ }^{14}$

1. Anak-anak yang lahir dalam zinah, yaitu anak yang lahir dari perhubungan orang lelaki dan orang perempuan, sedangkan salah satu dari mereka atau keduaduanya berada di dalam perkawinan dengan orang lain.

2. Anak-anak yang lahir dalam sumbang, yaitu anak yang lahir dari perhubungan orang lelaki dan orang perempuan, sedangkan di antara mereka terdapat larangan kawin, karena masih sangat dekat hubungan kekeluargaannya (Pasal $30)$.

Anak-anak sebagaimana tersebut di atas memuat Pasal 283 Kitab UndangUndang Hukum Perdata tidak dapat

14 Ali Afandi, 2004, Hukum Waris Hukum Keluarga Hukum Pembuktian, Cet. IV, PT. Rineka Cipta, Jakarta, HIm. 43. 
diakui. Mengenai hak waris anak-anak ini Pasal 867 Kitab Undang-Undang Hukum Perdata menentukan, bahwa mereka itu tidak dapat mewaris dari orang yang membenihkannya. Mereka hanya dapat nafkah untuk hidup. ${ }^{15}$

Menurut pemohon, pengaturan mengenai kedudukan anak luar nikah yang diatur dalam ketentuan Pasal 43 Undang-Undang Nomor 1 Tahun 1974 tentang perkawinan, selama ini dianggap tida cukup memadai dalam memberikan perlindungan hukum dan cendrung diskriminatif, status anak di luar nikah atau anak yang dilahirkan diluar perkawinan yang sah hanya memiliki hubungan keperdataan dengan ibunya dan keluarga ibunya tanpa adanya tanggungjawab dari ayah biologisnya.

Maka seperti yang telah diuraikan sebelumnya, Putusan Mahkamah Konstitusi Nomor 46/PUU-VIII/2010 mengabulkan permohonan pemohon terkait dengan status anak dalam Pasal 43. Dan putusan Mahkamah Konstitusi Nomor 46/PUU-VIII/2010 tidak mengabulkan gugatan pemohon dalam Pasal 2 yang terkait dengan pencatatan perkawinan.

Dampak positif Putusan Mahkamah Konstitusi Nomor 46/PUU-VIII/2010 menyatakan bahwa Pasal 43 ayat (1) Undang-Undang Nomor 1 Tahun 1974 tentang Perkawinan yang berbunyi:

“Anak yang dilahirkan di luar perkawinan hanya mempunyai

\footnotetext{
${ }^{15}$ Ibid, Hlm. 44.
}

hubungan perdata dengan ibunya dan keluarga ibunya".

Bertentangan dengan UndangUndang Dasar 1945 dan tidak memiliki kekuatan hukum mengikat sepanjang dimaknai menghilangkan hubungan perdata dengan laki-laki yang dapat dibuktikan berdasarkan ilmu pengetahuan dan teknologi dan/atau alat bukti lain menurut hukum ternyata mempunyai hubungan darah sebagai ayahnya, sehingga ayat tersebut harus dibaca, "anak yang dilahirkan di luar perkawinan mempunyai hubungan perdata dengan ibunya dan keluarga ibunya serta dengan laki-laki sebagai ayahnya yang dapat dibuktikan berdasarkan ilmu pengetahuan dan teknologi dan/atau alat bukti lain menurut hukum mempunyai hubungan darah, termasuk hubungan perdata dengan kelurga ayahnya".

Apabila dianalisa, maka logika hukumnya Putusan ini menimbulkan konsekuensi adanya hubungan nasab anak luar nikah dengan bapak biologisnya; adanya hak dan kewajiban antara anak luar nikah dan bapak biologisnya, baik dalam bentuk nafkah, waris dan lain sebagainya. Hal ini tentunya berlaku apabila terlebih dahulu dilakukan pembuktian melalui ilmu pengetahuan dan teknologi seperti: tes DNA dan lain ebagainya yang menyatakan bahwa benar anak diluar nikah tersebut memiliki hubungan darah dengan laki-laki sebagai ayah biologisnya tersebut. Dalam hal ini terbuka kesempatan bagi para anak diluar nikah untuk mendapatkan hak nafkah, waris dan lain sebagainya. 
Darda Pasmatuti: Analisa Terhadap Putusan Mahkamah Kontitusi No.46/PUU-VII/2010...

Dampak negatifnya putusan Mahkamah Konstitusi Nomor 46/PUUVIII/2010 dinilai melanggar ajaran Islam dan tatanan hukum Islam. Hukum Islam menyatakan bahwa, status anak diluar nikah dalam kategori yang kedua, disamakan statusnya dengan anak zina dan anak li'an, oleh karena itu maka mempunyai akibat hukum sebagai berikut: (a) tidak ada hubungan nasab dengan bapaknya. Anak itu hanya mempunyai hubungan nasab dengan ibunya. Bapaknya tidak wajib memberikan nafkah kepada anak itu, namun secara biologis ia tetap anaknya. Jadi hubungan yang timbul hanyalah secara manusiawi, bukan secara hukum. (b) tidak ada saling mewaris dengan bapaknya, karena hubungan nasab merupakan salah satu penyebab kewarisan. (c) bapak tidak dapat menjadi wali bagi anak diluar nikah. Apabila anak diluar nikah itu kebetulan seorang perempuan dan sudah dewasa lalu akan menikah, maka ia tidak berhak dinikahkan ole bapak biologisnya. ${ }^{16}$

Mahkamah Konstitusi dalam hal ini telah melampaui permohonan yang sekedar menghendaki pengakuan hubungan keperdataan atas anak dengan bapak hasil perkawinan tapi tidak dicatatkan di Kantor Urusan Agama (KUA) menjadi meluas mengenai hubungan keperdataan atas anak hasil hubungan zina dengan lelaki yang mengakibatkan kelahirannya. Majlis Ulama Indonesia (MUI) menilai putusan

16 Amir Syarifuddin, 2002, Meretas Kebekuan Ijtihad, Ciputat Press, Hlm.195.
Mahkamah Konstitusi ini sangat berlebihan, melampaui batas, dan bersifat "over dosis" serta bertentangan dengan ajaran Islam dan pasal 29 UndangUndang Dasar tahun 1945. ${ }^{17}$ Menurut Makruf, putusan Mahkamah Konstitusi itu memiliki konsekuensi yang sangat luas, termasuk mengesahkan hubungan nasab, waris, wali, dan nafkah antara anak hasil zina dan lelaki yang menyebabkan kelahirannya karena hal demikian tidak dibenarkan oleh ajaran Islam.

Akibat nyata putusan Mahkamah Konstitusi, kini kedudukan anak hasil zina dijadikan sama dengan kedudukan anak yang lahir dari hubungan perkawinan yang sah, baik dari segi kewajiban memperoleh nafkah dan terutama hak waris. Dengan demikian, sudah jelas putusan Mahkamah Konstitusi ini telah menyebabkan lembaga perkawinan menjadi kurang relevan apalagi sekedar pencatatannya, mengingat penyamaan hak antara anak hasil zina dengan anak hasil perkawinan yang sah. Hal ini sangat menurunkan derajat kesucian dan keluhuran lembaga perkawinan, bahkan pada tingkat ektrem dapat muncul pendapat tidak dibutuhkan lagi lembaga perkawinan karena orang tidak perlu harus menikah secara sah apabila dikaitkan dengan perlindungan hukum anak.

17 MUI: Putusan Mahkamah Konstitusi Sembrono, Over Dosis \& Bertentangan dengan Ajaran Islam, dikutip dari http://www.satumedia.info/diakses pada tanggal 28 Maret 2012 pada pukul 17.30 


\section{SIMPULAN DAN SARAN}

Anak luar nikah berdasarkan putusan MK ini mempunyai hubungan keperdataan dengan ibunya dan ayahnya selama dapat dibuktikan dengan ilmu pengetahuan jika anak memiliki hubungan darah dengan ayahnya. Jika terbukti maka anak tersebut statusnya diakui sebagai anak dari ayah biologisnya dan ketentuan hukum yang mengikutinya. Positifnya putusan MK tersebut dinilai memberikan jamin terhadap hak asasi manusia seperti yang diatur dalam UUD 1945, namun putusan tersebut bisa berlaku terhadap seluruh anak luar nikah, termasuk anak zina.

$\begin{array}{crr}\text { Saran } & \text { penelitian, } & \text { Sebaiknya } \\ \text { Mahkamah } & \text { Konstitusi } & \text { hanya } \\ \text { mengabulkan } & \text { permohonan } & \text { pemberian }\end{array}$ status anak luar kawin dari pernikahan siri bukan anak dari hasil zina. Karena tentunya hal ini membawa dampak yang bukan hanya teknis tetapi ideologis dan akidah umat Islam. Karena berdasarkan putusan tersebut tidak mempertimbangkan akibat dari pemberian status anak yang mempunyai hubungan nasab dengan ayah biologisnya. Sementara itu dalam permasalahan nikah siri, jika segala rukun nikah menurut agama Islam telah terpenuhi maka hasil perkawinan tersebut sah dan ayah dari anak yang lahir berdasarkan pernikahan sirri tetap diakui dan mempunyai garis nasab dengan anaknya dan itu bisa dibuktikan melalui ilmu pengetahuan jika tidak terdapat pencatatan atas pernihanannya. Harus ada Peraturan Pelaksana untuk menjalankan putusan
Mahkamah Konstitusi Nomor 46/PUUVIII/2010 yang dikeluarkan oleh Pemerintah. Tujuan dibentuk peraturan pelaksana dari Mahkamah Konstitusi Nomor 46/PUU-VIII/2010 agar pelaksanaanya tidak simpang siur pada prakteknya diberbagai pengadilan agama. Dengan mengeluarkan aturan pelaksana tesebut tidak akan membuat bingung majelis hakim pengadilan Agama di seluruh nusantara. Belajar dari janji yang terdapat dalam pasal 43 ayat (2) Undang Undang Nomor 1 Tahun 1974 Tentang Perkawinan untuk mengatur pelaksanaan mengenai nasab anak luar nikah hanya pada ibu biologisnya, akan diatur dengan Peraturan Pemerintah, tidak pernah direalisasikan oleh pemerintah berakibat pada tejadinya kekosongan hukum dalam hal aturan pelaksana. Hingga pada pelaksanaanya, majelis hakim pada berbagai Pengadilan Agama kembali merujuk pada Kitab Undang Undang Hukum Perdata (KUHPer). Majelis Hakim Pengadilan Agama di seluruh Indonesia harus diberi sosialisasi mengenai putusan Mahkamah Konstitusi Nomor 46/PUU-VIII/2010. Dengan demikian akan membuat kondisi mental Majelis Hakim Pengadilan Agama di seluruh Indonesia siap menghadapi berbagai gugatan terkait status anak luar nikah sebagai akibat putusan Mahkamah Konstitusi Nomor 46/PUU-VIII/2010. Dengan tahapan sosialisasi putusan Nomor 46/PUU-VIII/2010 akan membuat setiap hakim pada pengadilan agama mempelajarinya sambil menunggu peraturan pelaksana dari pemerintah terkait dengan peraturan pelaksan Putusan 
Darda Pasmatuti: Analisa Terhadap Putusan Mahkamah Kontitusi No.46/PUU-VII/2010...

Mahkamah Konstitusi Nomor 46/PUUVIII/2010 tentang status anak.

\section{UCAPAN TERIMAKASIH}

Puji dan Syukur penulis ucapkan ke hadirat Allah SWT yang telah memberikan Rahmat dan Karunia-Nya, sehingga akhirnya penulis dapat menyelesaikan penulisan karya ilmiah ini yang berjudul: "ANALISA TERHADAP PUTUSAN

\section{MAHKAMAH KONTITUSI}

\section{NOMOR 46/PUU-VIII/2010 MENGENAI STATUS ANAK"}

Penulis menyadari bahwa tanpa bantuan dan dorongan dari berbagai pihak tidak mungkin karya ilmiah ini dapat diselesaikan. Oleh karena itu pada kesempatan ini dengan segala kerendahan hati, penulis ingin mengucapkan terimakasih dan penghargaan yang sebesar-besarnya kepada:

1. Bapak Dr. Eviandi Ibrahim S.H., M.Hum selaku Ketua Sekolah Tinggi Ilmu Hukum Putri Maharaja Payakumbuh

2. Seluruh rekan-rekan Dosen Sekolah Tinggi Ilmu Hukum Putri Maharaja yang tidak dapat penulis sebutkan satu-persatu.

\section{DAFTAR PUSTAKA}

\section{Buku-buku}

Ali Afandi, Hukum Waris Hukum Keluarga Hukum Pembuktian, Cet.IV, PT. Rineka Cipta, Jakarta, 2004.

Amir Syarifuddin, Meretas Kebekuan Ijtihad, Ciputat Press, Jakarta, 2002.
Amir Syarifudin, Hukum Kewarisan Islam, Cet. II, Prenada Media, Jakarta, 2005.

Mahmud Yunus, Hukum Perkawinan Dalam Islam, Hidakarya agung, Jakarta, 1979.

Martiman Prodjohamijojo, Hukum Perkawinan Indonesia, Cet.II, Indonesia Legal Center Publishing, Jakarta, 2007.

Oemarsalim, Dasar-Dasar Hukum Waris di Indonesia, Cet. IV, Sinar Grafika, Jakarta, 2006.

Saidus Syahar, Undang-undang Perkawinan dan masalah Pelaksanaannya Ditinjau dari segi Hukum Islam, Alumni, Bandung, 1981.

Soedharyo Soimin, Hukum Orang dan Keluarga, Cet.II, Sinar Grafika, Jakarta, 2004.

Surini Ahlan Sjarif dan Nurul Elmiyah, Hukum Kewarisan Perdata Barat, Cet. II, Kencana Media Group, Jakarta, 2006.

Wahono Darmabrata dan Surini Ahlan Sjarif, Hukum Perkawinan dan Keluarga di Indonesia, Badan Penerbit Fakultas Hukum Universitas Indonesia, Jakarta, 2004.

Wirjono Prodjodikoro, Hukum Perkawinan di Indonesia, Vorkink van Hoeve, Bandung.

\section{Internet}

Boy Yendra Tamin, Kedudukan Anak Diluar Perkawinanan (Perkawinan Bawah Tangan) Pasca Putusan Mahkamah Konstitusi Nomor 46/PUUVIII/2010, seperti dikutip dari, http://boyyendratamin.blogspot.co $\underline{m}$ diakses pada 16 Juli 201220.00 Wib.

Dampak Perkawinan Bawah Tangan terhadap Anak, http://www.lbh- 
Jurnal Cendekia Hukum: Vol. 3, No 1, September 2017

apik.or.id., diakses pada tanggal 28 Juni 2012, 16.00 wib.

MUI : Putusan Mahkamah Konstitusi Sembrono, Over Dosis \&

Bertentangan dengan Ajaran

Islam, dikutip dari

http://www.satumedia.info/

diakses pada tanggal 28 Maret 2012 17.30 Wib.

\section{Peraturan Perundang-Undangan}

Undang Undang Dasar Tahun 1945.

Kitab Undang Undang Hukum Perdata (KUHper).
Undang Undang Nomor 1 Tahun 1974 Tentang Perkawinan.

Undang Undang Nomor 24 Tahun 2003 Tentang Mahkamah Konstitusi yang telah direvisi dengan Undang Undang Nomor 8 tahun 2011.

Keputusan Presiden Nomor 1 Tahun 1991 tentang Kompilasi Hukum Islam (KHI).

Keputusan Mahkamah Konstitusi Perkara Nomor 46/PUU-VIII/2010. 